\title{
BOTTLED UP
}

\section{BY ANATOLY BELILOVSKY}

CC

"Y ou won't like it," said the corkscrew. "A most dis-

appointing product, not what I expect from a Grand Cru winery at all. Hardly any nose to speak of, and the tannins are totally unbalanced. You really should pull me out of this cork, lay the bottle down for a few more years, and make yourself a nice cup of tea."

He'd made it for her once and she'd pretended he'd got it right but he knew he hadn't. The tea she made herself was so much better, its aroma suffused the whole house. She would sit in that enormous old chair in her comfy old sweater two sizes too big, feet tucked under her, nose in the teacup, eyes half shut behind steamed-over glasses, her smile would light up the room more than the fireplace ever did, and he would just sit and look at her for hours on end.

He might be looking at her still if she weren't dead.

"Just pop it," he said through his teeth, eyes blurring, hands beginning to shake.

"Are you going to chug the wine?" asked the corkscrew.

He looked around, opened a cabinet, selected a glass.

"That's a white-wine glass," said the corkscrew.

"So?"

"The volatile scents won't be properly concentrated," said the corkscrew. "It will interfere with the proper enjoyment of the wine".

"What are you, my mother?" he said.

"No, I am not your mother. I am Smorkscrew, a beverage-management solution equipped with artificial intelligence. Now, what food were you considering to accompany this wine?"

He looked around again, pointed at a dish. "This?" he said.

"Peanuts?" said the corkscrew. "That would be an insult even to this inferior excuse for a Valpolicella. Haven't you got any cheese? Fresh mozzarella would be perfect. Or turkey prosciutto and melon. Be sure to

DNATURE.COM Follow Futures: y @NatureFutures f go.nature.com/mtoodm slice the prosciutto very thin -"

"She's dead!" he shouted. "Can't you get that through

\section{Hard to swallow.}

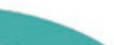

